Jurnal Ilmu Ilmu Agribisnis: Journal of Agribusiness Science, 9(3), Agustus 2021

\title{
RANTAI NILAI (VALUE CHAIN) AGRIBISNIS KOPI ROBUSTA RAKYAT: STUDI KASUS DI KABUPATEN EMPAT LAWANG PROVINSI SUMATERA SELATAN
}

\author{
(Value Chain of Small-Scale Robusta Coffee Agribusiness: A Case Study in Empat Lawang District South Of \\ Sumatera Province)
}

Putri Suci Asriani ${ }^{*}$, Armeitha Suryani ${ }^{2}$
${ }^{1}$ Dosen Jurusan Sosial Ekonomi Pertanian Faperta Universitas Bengkulu-Jalan Raya WR Supratman, Kandang Limun, Kota Bengkulu, e-mail: putriasriani@gmail.com
${ }^{2}$ Alumni Prodi Agribisnis Faperta Universitas Bengkulu/Praktisi Kopi di Desa Karang Caya Kabupaten Empat Lawang Provinsi Sumatera Selatan

\begin{abstract}
The absence of routine counseling and cooperatives that can work together also makes farmers still have to independently decide the direction of their business. In addition, the coffee processing industry is still very minimal. The majority of existing coffee products are sold in the form of dried coffee bean directly to collector traders. This study aims to analyze the value chain of coffee produced by value chain actors, and the potential for agribusiness development of robusta coffee in Karang Caya Village, Pendopo Barat District, Empat Lawang Regency. In this study, primary and secondary data were used which were analyzed using value chain analysis (VCA) and discussed in descriptive analysis. Research respondents involved were smallholder coffee farmers, agro-industry players, traders, and local government officials who understand the prospects for developing coffee farming in the research location. Based on the results of the study, it is known that there are 3 marketing channels for coffee, namely: farmers $\rightarrow$ subdistrict collectors $\rightarrow$ wholesalers $\rightarrow$ end consumers; farmers $\rightarrow$ end consumers; and farmers $\rightarrow$ coffee processors $\rightarrow$ end consumers. The dominance of farmers as the main actors in the activities of supply to marketing of coffee is very visible, the role of groups and other institutions is very minimal. Uneven distribution of values results in inefficient channels. This condition results in the price setting being carried out by the buyer (price setter) while the seller acts as the price taker.
\end{abstract}

Key words: Robusta coffee, smallholder farmer, value chain

\section{PENDAHULUAN}

Kopi merupakan sumberdaya pertanian bernilai tinggi dan memiliki jangkauan pasar yang sangat luas dengan berbagai tingkatan segmentasi. Indonesia merupakan salah satu negara produsen kopi terbesar di dunia, berdasarkan data Kementan (2019) disampaikan bahwa Indonesia selaku produsen kopi berada pada urutan ke-4 setelah Brazil, Vietnam, dan Kolombia. Besaran kuantitas produksi kopi Indonesia per tahun rata-rata 9 persen dari total produksi kopi dunia. Di pasaran dunia, kopi Indonesia selain di perdagangkan dalam bentuk green bean juga dalam bentuk produk kopi olahan. Pada tahun 2018, tingkat ekspor produk kopi olahan mengalami kenaikan sebesar 19,1 persen dibandingkan tahun sebelumnya. Dominasi produk kopi olahan berupa kopi instant, ekstrak, essence, dan konsentrat kopi dengan pasar tujuan utama ke wilayah ASEAN, China, dan Uni Emirat Arab.
Besarnya potensi bisnis perkopian di Indonesiadidukung dengan tingginya produksi di daerah-daerah sentra produksi yang tersebar hampir di seluruh wilayah Indonesia. Berdasarkan data Kementan (2017) disampaikan bahwa konstribusi produksi rata-rata tahun 2014-2018 terbesar sebanyak 96 persen disumbangkan dari produksi Perkebunan Rakyat (PR) yang tersebar di 6 (enam) provinsi sentra produksi, yaitu Sumatera Selatan, Lampung, Jawa Timur, Sumatera Utara, Aceh, dan Bengkulu. Pulau Sumatera berkontribusi sebesar 63,99 persen, Provinsi Jawa Timur 9,56 persen, dan selebihnya sekitar 26,45 persen produksi kopi Indonesia disumbangkan dari provinsi-provinsi lainnya.

Pulau Sumatera sebagai lumbung kopi bagi negara Indonesia sangat potensial menghasilkan dominasi komoditi kopi robusta sebagai komoditi ekspor unggul yang mampu menghasilkan devisa bagi negara. Provinsi yang memiliki jumlah produksi - 
kopi terbesar secara nasional adalah Provinsi Sumatera Selatan. Rata-rata produksi yang dihasilkan mencapai 30 persen dari total produksi nasional (Kusnandar, 2019). Produksi kopi di Sumatera Selatan didominasi oleh perkebunan kopi rakyat yang dikelola dengan sistem manajemen yang masih sangat tradisional.

Kabupaten Empat Lawang merupakan salah satu kabupaten di Provinsi Sumatera Selatan yang masyarakatnya mayoritas bemata pencaharian di sektor pertanian. Sebanyak 49,42 persen penduduk Kabupaten Empat Lawang menggantungkan hidupnya pada aktivitas pertanian, terutamanya di subsektor perkebunan, yaitu perkebunan kopi, kelapa sawit, dan karet. Tanaman kopi adalah komoditi yang paling banyak dibudidayakan, hampir di setiap daerah di Kabupaten Empat Lawang memiliki kebun kopi dengan hasil yang dapat diandalkan. Pada tahun 2018 produksi kopi mencapai 70,40 persen dari total produksi komoditi perkebunan di Kabupaten Empat Lawang ini, sisanya sebesar 16,40 persen dari karet dan 13,20 persen dari kelapa sawit (BPS, 2020).

Besarnya produksi kopi di tingkat petani rakyat tentunya membutuhkan kesiapan pasar yang mampu menyerap produk dengan nilai tambah yang baik. Di Kabupaten Empat Lawang komoditi kopi belum mendapatkan perhatian yang serius. Permasalahan yang dihadapi agribisnis kopi mulai dari subsektor hulu sampai dengan hilir. Permasalahan mulai di subsektor hulu terkait pada ketersediaan benih/varietas unggul, dimana sampai dengan saat ini masih menjadi masalah besar sebab belum adanya pembudidaya kopi dan kebun induk di tingkat rakyat. Demikian halnya dengan di subsektor hilir terutama terkait penanganan pasca panen dan akses terhadap pasar ekspor masih sangat lemah, petani sangat tergantung pada keberadaan pengepul dan pedagang besar yang membeli langsung apa adanya komoditi kopi yang dihasilkan. Tentunya situasi ini akan menyebabkan petani tidak memiliki daya saing yang kuat dalam menentukan harga.

Potensi sumberdaya kopi yang diusahakan oleh petani di desa ini berlimpah, namun proses usahatani yang dilakukan belum terlalu maksimal karena masih menggunakan sistem konvensional. Petani tidak memiliki modal yang dikhususkan dalam kegiatan usahatani mereka (minim modal), sehingga penggunaan input menjadi tidak sesuai dengan kebutuhan yang seharusnya. Belum adanya penyuluhan rutin dan koperasi yang dapat bekerjasama juga membuat petani masih harus berdiri sendiri. Selain itu, pengolahan lanjutan juga masih sangat minim. Hasil kopi yang ada kemudian biasanya hanya dijual dalam bentuk kopi beras secara langsung kepada pedagang pengumpul. Selain kopi beras, kopi juga diolah menjadi bubuk kopi yang pengolahannya hanya sebatas untuk memenuhi kebutuhan konsumsi skala kecil seperti pada tingkat konsumsi keluarga dan warung-warung. Padahal komoditi kopi ini memiliki potensi besar untuk dikembangkan.

Banyak lembaga yang berperan dalam agribisnis kopi ini, dan tentunya setiap lembaga mengharapkan besaran nilai tambah yang sepadan juga. Analisis rantai nilai pada agribisnis kopi merupakan alat analisis yang dapat mengidentifikasi besaran nilai tambah yang dapat dinikmati tiap-tiap lembaga yang terlibat dalam agribisnis kopi mulai dari subsektor hulu ke hilir. Penelitian ini bertujuan untuk menganalisis rantai nilai kopi yang dihasilkan oleh pelaku rantai nilai, dan potensi pengembangan agribisnis kopi robusta di Desa Karang Caya Kecamatan Pendopo Barat Kabupaten Empat Lawang.

\section{METODE PENELITIAN}

Penelitian dilaksanakan di Desa Karang Caya Kecamatan Pendopo Barat Kabupaten Empat Lawang Provinsi Sumatera Selatan secara purposive sampling dengan dasar pertimbangan bahwa di desa ini mayoritas penduduknya (mencapai 80\%) melakukan usahatani kopi secara turun temurun dan merupakan salah satu desa penghasil kopi terbesar di tingkat kecamatan. Pengambilan data penelitian dilakukan dalam rentang waktu bulan Juni-November tahun 2020.

Metode yang digunakan dalam penelitian ini adalah metode kuantitatif dan kualitatif. Metode penelitian kuantitatif digunakan dalam analisis rantai melalui analisis produksi, harga, biaya, penerimaan, pendapatan, dan nilai tambah. Dikutip dari Sahidu et al (2018) disampaikan bahwa metode kualitatif digunakan dalam menganalisis perilaku manusia yang bersifat subjektif, dengan melihat sudut pandang (persepsi) responden sebagai subjek dalam pandangan yang bersifat objektif terhadap pengelolaan agribisnis kopi. Selanjutnya dengan metode deskriptif dilakukan value chain analysis (VCA) dan dilanjutkan dengan perumusan potensi pengembangan yang dimungkinkan di tiap-tiap lembaga. 
Pendekatan studi kasus dalam penelitian ini merupakan suatu proses pengkajian dan pengumpulan data secara mendalam dari semua pelaku rantai nilai kopi di Desa Karang Caya. Dalam penelitian pemasaran ini dilakukan penelusuran pelaku di setiap tahapan rantai pemasarannya dengan menggunakan pendekatan snowball sampling, dimulai dari petani kopi sampai dengan konsumen akhir yang terjangkau dalam penelitian ini (Neuman, 1994; Nisbet, J. Dan J. Watt, 1994).

Variabel yang diamati dan diukur antara meliputi (1) proses-proses utama dalam rantai nilai kopi, (2) profil pelaku rantai nilai kopi, (3) aktivitas pelaku di setiap rantai nilai, (4) potensi sumberdaya manusia setiap pelaku, (5) nilai tambah yang dinikmati dan share peluang lapangan kerja yang dihasilkan, dan (6) kendala dan peluang dalam peningkatan kinerja rantai nilai.

\section{HASIL DAN PEMBAHASAN}

\section{Sistem Agribisnis Kopi}

Sistem agribisnis kopi di Desa Karang Caya terdiri dari subsistem sarana input produksi, subsistem usahatani, subsistem pengolahan, subsistem pemasaran, dan subsistem penunjang. Setiap subsistem memberikan input kepada subsistem berikutnya dengan dukungan subsistem lembaga penunjang, walaupun sistem pendukungnya belum berjalan dengan baik. Hubungan yang terjadi antar subsistemagribisnis kopi di Desa Karang Caya masih parsial dengan hubungan searah, belum terjadi hubungan timbal balik dan terkoordinasi di antara subsistem-subsistem tersebut sebagaimana diilustrasikan pada Gambar 1.

Subsistem Penyedia Sarana Input Produksi merupakan subsistem yang berperan dalam penyediaan input produksi pada sistem agrbisnis kopi di Desa Karang Caya. Subsistem sarana input produksi yang ada pada sistem agribisnis kopi di Desa Karang Caya adalah (1) unit penyedia bibit kopi, (2) unit penyedia pupuk, (3) unit penyedia pestisida dan herbisida, (4) unit penyedia alat dan mesin pertanian, dan (5) unit penyedia modal, tenaga kerja, dan teknologi.

Bibit yang digunakan dalam sistem agribisnis kopi d Desa Karang Caya adalah bibit asalan yang diproduksi oleh petani secara langsung melalui pembibitan biji kopi. Adapun biji kopi untuk pembibitan diperoleh petani dari petani lain, dengan standar kualitas biji yang ditentukan oleh petani sendiri seperti buah kopi yang sudah masak sempurna dengan kondisi biji yang besar.

Pupuk diperoleh petani dari kios-kios pertanian yang tersebar di luar desa (pasar). Adapun penggunaan pupuk pada subsistem agribisnis kopi di Desa Karang Caya sangat beragam baik jenis dan jumlah yang digunakan petani. Pupuk digunakan untuk meningkatkan hasil produksi kopi. Adapun Ketersediaan pupuk di kios-kios pertanian sudah mampu mencukupi kebutuhan pupuk petani, artinya ketersediaan pupuk bagi petani dapat terjamin. Namun jenis pupuk yang digunakan petani kopi di Desa Karang Caya adalah pupuk non-subsidi, sedangkan pupuk subsidi sulit diperoleh karena ketidakaktifan kelompok tani kopi yang sudah dibentuk.

Pestisida dan herbisida digunakan oleh petani di Desa Karang Caya untuk memberantas hama dan gulma. Pestisida dan herbisida ini juga diperoleh dari kios-kios luar desa (pasar) dengan pembelian secara tunai. Adapun penggunaan dari pestisida dan herbisida ini beragam sesuai kebutuhan masng-masing petani. Ketersediaan pestisida dan herbisida di kios-kios pertanian selalu ada.

Tenaga kerja yang digunakan oleh petani di Desa Karang Caya merupakan tenaga kerja yang berasal dari dalam desa. Ketersediaan tenaga kerja luar keluarga cukup sulit untuk didapatkan saat musim panen tiba, dikarenakan jadwal panen yang hampir sama sehingga petani harus berbagi tenaga kerja kepada petani lain.

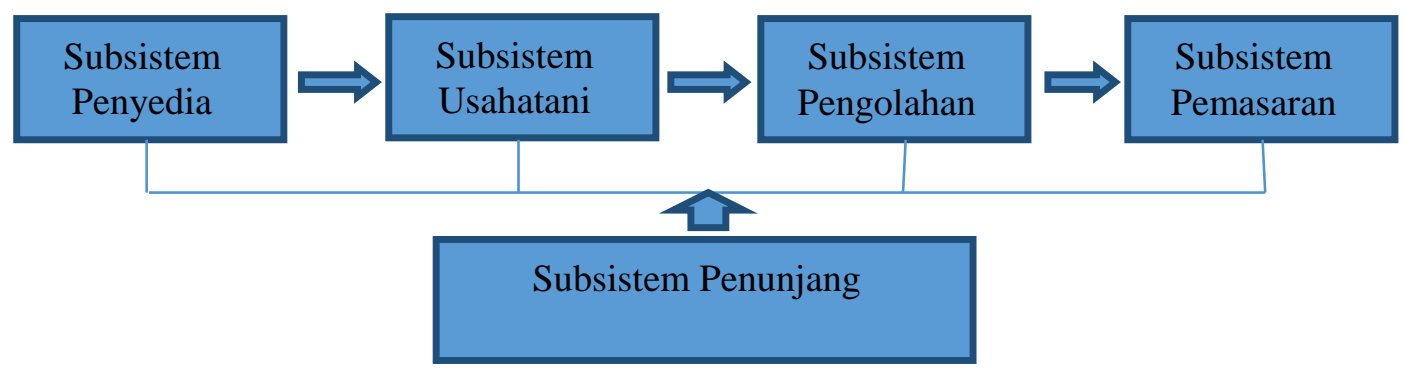

Gambar 1. Sistem Agribisnis Kopi di Desa Karang Caya 
Sedangkan untuk kegiatan lain seperti penanaman, pemeliharaan, pemupukan, dan penyemprotan lebih banyak dilakukan oleh petani itu sendiri (tenaga kerja dalam keluarga).

Subsistem Usahatani merupakan subsistem yang meliputi kegiatan penamanam, pemeliharaan (penyulaman, penyiangan), pemupukan, penyemprotan, panen, dan pasca panen. Pada subsistem ini kegiatan dilakukan oleh petani masing-masing strata sesuai kebutuhan usahatani masing-masing. Kegiatan usahatani dilakukan sesuai dengan keadaan usahatani kopi petani mulai dari penanaman hingga pasca panen. Namun kegiatan ini akan berlangsung hampir bersamaan dengan petani-petani lain walau akan ada perbedaan pada input-input yang diberikan oleh petani. Perbedaan ini disebabkan adanya perbedaan aktivitas tambahan petani seperti bekerja, dan adanya perbedaan ketersediaan biaya yang dimiliki oleh petani.

Subsistem Pengolahan pada petani kopi di Desa Karang Caya meliputi pengolahan kopi beras (coffee bean) menjadi kopi bubuk. kegiatan pengolahan ini dilakukan oleh wanita tani dengan menggunakan bahan baku yang dihasilkan dari usahatani kopi, baik dari hasil usahatani sendiri atau membeli kepada petani lain jika ketersediaan bahan baku kopi beras dirasa kurang mencukupi. Pengolahan kopi bubuk ini dapat memberikan nilai lebih bagi petani. Namun pengolahan ini masih dilakukan secara sederhana, begitu pula untuk proses pemasaran yang ada. Hasil olahan kopi bubuk dijual petani pengolah di warung-warung sekitaran desa dan dijual ke luar kota atas dasar pemesanan. Adapun untuk proses promosi belum digunakan dalam kegiatan pemasaran produk hasil olahan kopi bubuk ini.

Subsistem Pemasaran dalam sistem agribisnis kopi di Desa Karang Caya berfungsi untuk memasarkan hasil dari subsistem usahatani dan subsistem pengolahan kopi. Pada subsistem pemasaran untuk kopi beras sudah berjalan dengan baik. Kegiatan pemasaran dilakukan dengan cara petani menjual kopi beras kepada pedagang pengumpul yang terdapat di luar desa, kemudian pedagang pengumpul menjual kopi beras ke luar kota, antara lain ke Lampung dan Surabaya. Namun tidak demikian dengan pemasaran kopi bubuk, pemasarannya masih belum maksimal. Semua aktivitas pemasaran dilakukan sendiri oleh petani pengolah dengan menjual kopi di warung dan konsumen luar kota atas dasar pesanan. Belum bekerja baikknya aktivitas pemasaran ini juga disebabkan masih lemahnya kemampuan petani (sebagai aktor utamanya) dalam menentukan kualitas kopi, penentuan harga, dan promosi yang belum optimal.

Subsistem Penunjang merupakan subsistem yang berperan dalam sistem agribisnis kopi. Dalam sistem agribisnis kopi di Desa Karang Caya, peran subsistem penunjang masih belum maksimal. Peran kelompok tani kopi yang telah terbentuk di Desa Karang Caya masih sangat minimumdan kinerjanya tidak berjalan dengan baik. Kelompok tani hanya dibentuk tanpa adanya aktivitas yang dapat memberi umpan balik bagi anggotanya, sehingga hal ini cukup menyulitkan petani untuk mendapat akses sarana prasarana produksi pertanian, antara lain bibit bersertifikat, alat pertanian dan teknologi budidaya pertanian, hingga memperoleh pupuk bersubsidi. Selain di subsistem budidaya, subsistem penunjang juga sangat diharapkan petani untuk dapat meningkatkan efisiensi kinerja subsistemsubsistem lainnya, antara lain subsistem pengolahan dan pemasaran kopi.

\section{Pelaku Rantai Nilai Agribisnis Kopi}

Rantai nilai menunjukkan bagaimana sebuah produk bergerak dari tahap bahan baku ke pelanggan akhir (Dewi et al., 2019). Rantai nilai ini menggambarkan aktivitas keterkaitan antara pemasok produk sampai dengan konsumennya. Pelaku yang terlibat dalam rantai nilai agribisnis kopi robusta di Desa Karang Caya terdiri dari perorangan individu petani, pengolah, dan pedagang pengumpul di seputaran bisnis kopi.

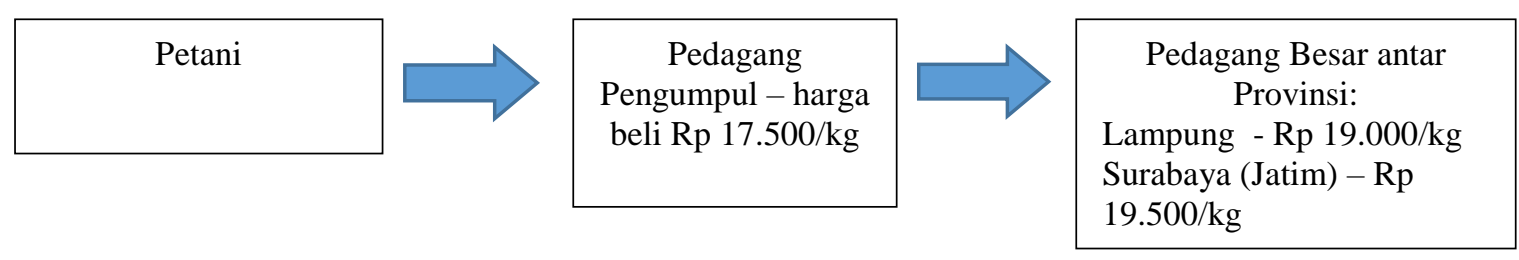

Gambar 2. Pola Aliran dalam Rantai Nilai Kopi Beras di Desa Karang Caya 
Rantai nilai yang terjadi merupakan mata rantai penyedia produk mulai dari sarana prasarana produksi hingga produk kopi robusta sampai dengan ke konsumennya. Pada rantai nilai terdapat tiga aliran yang dijalankan, yaitu aliran produk dari hulu ke hilir

Kopi yang dihasilkan petani dalam usahatani kopi di Desa Karang Caya sebagian besar dijual kepada pedagang pengumpul dan sebagian lagi diolah sendiri menjadi kopi bubuk. Pembayaran hasil penjualan kopi petani dilakukan secara tunai oleh lembaga pemasaran. Adapun untuk kopi bubuk yang dijual oleh petani sampai ke tangan konsumen tanpa melalui lembaga pemasaran. Pola aliran dalam rantai nilai kopi beras dapat dilihat pada Gambar 2.

Berdasarkan Gambar 2 dapat diketahui bahwa rantai nilai kopi robusta yang terbentuk di Desa Karang Caya masih sangat sederhana. Secara umum hanya terdapat 3 pelaku yang terlibat dan belum ada sama sekali upaya kelembagaan pemasaran resmi yang dilibatkan. Petani secara perorangan atau kelompok-kelompok kecil yang terbentuk secara alamiah akan memasuki pasar kopi dengan posisi tawar yang sangat lemah.

Rantai nilai kopi beras mulai terbentuk dari aktivitas petani menjual kopi beras kepada pedagang pengumpul, selanjutnya pedagang pengumpul menjual kopi kepada pengusaha kopi luar kota yang dalam penelitian ini terdapat dua kota tujuan yaitu Lampung dan Surabaya. Saat proses pemasaran petani membawa hasil usahatani ke pedagang pengumpul secara langsung dengan biaya angkut ditanggung oleh petani, kemudian pedagang pengumpul membawa kopi yang telah ditampung kepada pengusha kopi luar kota dengan biaya angkut yang juga ditanggung oleh pedagang pengumpul itu sendiri.

Saluran rantai nilai ini menggambarkan bahwa rantai nilai agribisnis kopi robusta yang terbentuk di Desa Karang Caya masih sangat sederhana dan belum mampu menghasilkan nilai ekonomi yang efisien dikarenakan sistem penanganan usahataninya yang belum intensif. Namun hal ini tidak terjadi pada rantai nilai agribisnis kopi bersertifikat di Kabupaten Lampung Barat (Dewi et al., 2019) yang menjelaskan bahwa seluruh saluran rantai nilai agribisnis kopi bersertifikat menguntungkan bagi masing-masing lembaga (pelaku) yang terlibat dikarenakan adanya peran kelembagaan yang terbentuk. Demikian juga halnya dengan hasil penelitian Widyaningtyas (2014) yang menyampaikan bahwa pembagian keuntungan yang merata di antara para pelaku rantai nilai dikarenakan besaran keuntungan di masing-masing saluran lebih besar dari biaya yang dikeluarkan.

Informasi terkait permintaan produk mengalir dari rantai pemasaran terakhir pada penelitian ini yaitu pedagang besar hingga ke petani, dan sebaliknya. Adapun pola pemasaran menujukkan aliran rantai pasok kopi beras yang $\mathrm{s}$ dimulai dari petani sebagai produsen kopi. Kopi beras yang telah siap panen dipetik secara manual oleh petani kemudian dijual dengan harga Rp17.500/Kg kepada pedagang pengumpul, selanjutnya pihak pengumpul menjual kopi beras ke pedagang besar di Lampung dengan harga $\mathrm{Rp} 19.000 / \mathrm{Kg}$ dan dan pedagang besar di Surabaya dengan harga $\mathrm{Rp} 19.500 / \mathrm{Kg}$.

Selain dalam bentuk kopi beras (coffee bean), produk yang dihasilkan juga berupa kopi bubuk, walaupun sampai dengan saat penelitian ini dilakukan masih dalam kapasitas yang sangat kecil dan belum kontinyu. Pengolahan kopi bubuk dilakukan oleh petani yang kemudian dipasarkan langsung ke konsumen tanpa melalui lembaga pemasaran. Kopi bubuk sebagian besar dijual kepada konsumen rumah tangga dan sebagian dijual kepada konsumen luar kota melalui pemesanan dari konsumen dengan biaya angkut yang ditanggung oleh konsumen. Untuk melihat lebih jelas alur pemasaran kopi bubuk di Desa Karang Caya dapat dilihat pada Gambar 3.

Berdasarkan Gambar 3 dapat diperoleh dua pola aliran, yaitu :
a. Pola I : Petani Pengolah $\rightarrow$ Konsumen Rumah Tangga
b. Pola II : Petani Pengolah $\rightarrow$ Konsumen Luar Kota

Rantai nilai kopi bubuk dimulai dari petani pengolah menjual kopi bubuk langsung kepada konsumen akhir yang pada penelitian ini terbagi menjadi konsumen rumah tangga dan konsumen luar kota.

Aliran uang pada rantai nilai kopi bubuk mengalir dari konsumen akhir yakni konsumen rumah tangga dan konsumen luar kota. Pada penelitian ini rantai pemasaran sampai pada konsumen akhir 
yang menjadi tujuan petani pengolah menjual kopi bubuk, sehingga aliran uang pada rantai nilai kopi bubuk juga pendek karena hanya dua saluran. Adapun sistem pembayaran pada tingkat petani pengolah dilakukan secara langsung sesuai dengan jumlah kopi bubuk yang dijual kepada konsumen akhir.

Aliran informasi pada anggota rantai pasok kopi bubuk sudah terintegrasi cukup baik. Informasi mengalir dari rantai pemasaran terakhir pada penelitian ini yaitu konsumen akhir hingga ke petani pengolah, dan sebaliknya. Adapun pola I dan pola II menujukkan aliran rantai pasok kopi bubuk yang sama dimulai dari petani pengolah sebagai produsen kopi. Kopi beras yang telah dipilih dan dibersihkan kemudian disangrai secara tradisional oleh petani pengolah, lalu dijual dengan harga $\mathrm{Rp} 60.000 / \mathrm{Kg}$ kepada konsumen akhir.

\section{Potensi Pengelolaan Agribisnis Kopi Robusta}

Petani harus memperhatikan input produksi yang digunakan dalam agirbisnis kopi, mulai dari proses pembibitan yang harus dilakukan secara lebih baik dengan memperhatikan kualitas biji kopi yang akan dijadikan bibit sesuai standar dari dirjen perkebunan. Petani juga harus mulai menggunakan pupuk yang sesuai anjuran sehingga hasil akan lebih optimal. Kekurangan ini juga harus dibantu dengan pemerintah desa yang menjadi wadah bagi petani dalam mendapatkan akses-akses yang diperlukan oleh petani seperti melalui kelompok tani, BUMDes (Badan Usaha Milik Desa), dan juga penyuluh yang dapat memberikan informasi mengenai kebutuhan input produksi yang seharusnya dibutuhkan oleh petani dan untuk menunjang kebutuhan petani.

Petani juga harus mulai memperhatikan setiap kegiatan usahatani kopi yang dilakukan mulai dari kegiatan budidaya seperti menanam kopi sesuai dengan jarak yang dianjurkan sehingga tanaman kopi dapat tumbuh secara optimal, proses pemupukan yang tidak sembarangan seperti dicampur dengan pestisida, proses panen dengan petik pilih (tidak melakukan pemetikan keseluruhan pada buah yang belum tua), juga proses pasca panen dengan tidak menyimpan kopi ceri lebih dari $2 \times 24$ jam ( dua hari) sehingga kualitas ceri kopi masih bagus.

Pengolahan kopi bubuk dapat lebih ditingkatkan lagi oleh petani pengolah dengan melakukan proses pemilihan kualitas bahan baku hingga proses pengemasan, sehingga dapat menjangkau pemasaran secara lebih luas. Proses pengolahan ini juga perlu dibantu oleh pembimbing UMKM agar petani pengolah dapat mengolah kopi bubuk dengan standar kulaitas dan kuantitas yang lebih baik.

Kegiatan pemasaran kopi beras yang melibatkan pedagang pengumpul di luar desa dapat menjadi suatu inovasi bagi petani kopi di Desa Karang Caya dan juga pemerintah desa untuk mengembangkan kelompok atau kelembagaan yang dibangun dari dalam desa, sehingga kegiatan pemasaran dapat dilakukan oleh petani dengan harga yang mampu bersaing. Peran BUMDES akan membantu petani dalam mendapatkan harga yang jauh lebih baik dengan adanya sistem pemasaran yang terintegrasi. Pemasaran kopi bubuk masih berada pada lokasi pemasaran yang sempit sehingga perlu adanya peningkatan skala pasar lebih luas oleh petani pengolah dengan melakukan promosi/pengenalan produk ke daerah dengan jangkauan lebih luas.

Lembaga penunjang baik lembaga pemerintah maupun swasta, harus lebih memperhatikan petanipetani kopi sehingga petani dapat menjalankan usahatani kopi secara lebih baik dan menghasilkan kopi dengan mutu serta jumlah yang lebih baik. Lembaga pemerintahan daerah dapat mengerahkan tenaga penyuluh untuk membantu petani dalam mengolah usahatani kopi yang ada.

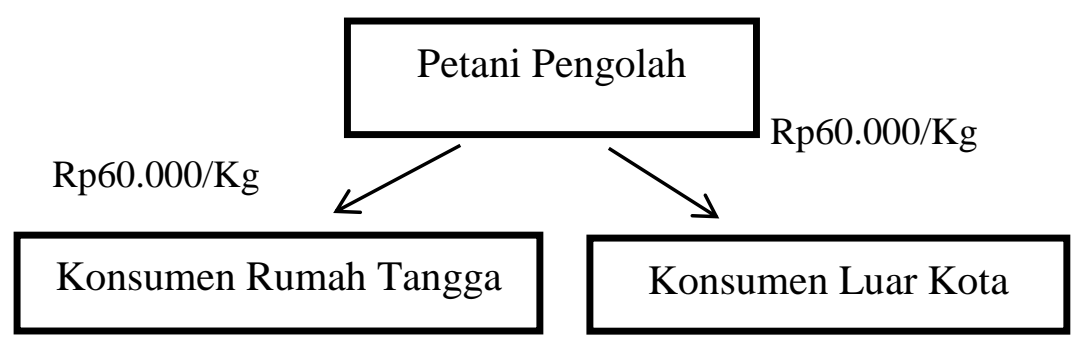

Gambar 3. Pola Aliran dalam Rantai Nilai Kopi Bubuk di Desa Karang Caya 
Mewujudkan daya saing komoditas kopi di era pasar bebas memerlukan strategi pengembangan rantai nilai yang mampu menciptakan dan mendistribusikan nilai tambah di antara para pelaku yang terlibat. Sebagaimana disampaikan Noor TI, Pardian P, Nugraha A (2016) bahwa penciptaan nilai tambah merupakan upaya mewujudkan efisiensi usaha, sehingga dengan dilengkapi proses pendistribusian nilai yang baik maka suatu pengelolaan usaha akan dapat berjalan dengan baik dan optimal.

\section{KESIMPULAN}

Sistem agribisnis kopi di Desa Karang Caya terdiri dari subsistem sarana input produksi, subsistem usahatani, subsistem pengolahan, subsistem pemasaran, dan subsistem penunjang. Setiap subsistem memberikan input kepada subsistem berikutnya dengan dukungan subsistem lembaga penunjang, walaupun sistem pendukungnya belum berjalan dengan baik. Hubungan yang terjadi antar subsistem agribisnis kopi di Desa Karang Caya masih parsial dengan hubungan searah, belum terjadi hubungan timbal balik dan terkoordinasi di antara subsistem-subsistem tersebut.

Rantai nilai agribisnis kopi robusta yang terbentuk di Desa Karang Caya masih sangat sederhana dan belum mampu menghasilkan nilai ekonomi yang efisien dikarenakan sistem penanganan usahataninya yang belum intensif. Terdapat berbagai potensi yang dapat dikembangkan guna mewujudkan formulasi strategi pengembangan rantai nilai yang mampu menciptakan dan mendistribusikan nilai tambah di antara para pelaku yang terlibat.

\section{DAFTAR PUSTAKA}

BPS [Badan Pusat Statistik]. 2020. Kabupaten Empat Lawang Dalam Angka 2019. http://www.empatlawang.go.id. [17 Desember 2020]

Dewi ANC, Arifin B, Marlina L. 2019. Rantai Nilai Agribisnis Kopi Sertifikasi di Kabupaten Lampung Barat. Jurnal Ilmu Ilmu Agribisnis 7(3): 285-291.

Kementerian Pertanian. 2017. Statistik Pertanian. http://www.pertanian.go.id. [17 Desember 2020]

Kementerian Pertanian. 2019. Statistik Pertanian. http://www.pertanian.go.id. [17 Desember 2020]

Neuman, W.L. 1994. Social Research Method: Qualitative and Quantitative Approach (2nd Edition). Allyn and Bacon. Sydney.

Nisbet J, dan J Watt. 1994. Studi Kasus Sebuah Panduan Praktis. PT. Gramedia Widiasarana Indonesia. Jakarta

Noor TI, Pardian P, Nugraha A. 2016. Analisis Rantai Nilai (value chain) Bawang Merah di Jawa Barat. Agrocore-Jurnal Agribisnis dan Social Ekonomi Pertanian, 1(1): 8-18.

Sahidu A, Muktasam, Nurjannah S, Hayati. 2018. Analisis Rantai Nilai Kemiri dan Strategi Pemberdayaan Petani: Studi Kasus di Desa Batudulang Kecamatan Batulanteh Kabupaten Sumbawa. Agrimansion, 19(01): 1-14.

TPSA [Canada-Indonesia Trade and Private Sector Assistance Project]. 2017. Analisis Rantai Nilai Global untuk Ekspor Kopi Indonesia (Laporan Penelitian). http://www.tpsaproject.com/wpcontent/uploads/2018-01-30-Report-IDN1211.03c.pdf. [17 Desember 2020]

Widyaningtyas D, Raharto S, Agustina T. 2014. Analisis Efisiensi Pemasaran Kopi Arabika di Desa Karangpring Kecamatan Sukorambi Kabupaten Jember. BIP 1(1): 1-10 